\title{
Lactose Utilization by Pseudomonas maltophilia
}

\author{
W. E. LOWE ${ }^{1}$ and W. M. INGLEDEW \\ Agricultural Microbiology Section, Department of Dairy and Food Science, University of Saskatchewan, \\ Saskatoon, Saskatchewan, Canada
}

\begin{abstract}
The type species (ATCC 13637) and one other strain (ATCC 17444) of Pseudomonas maltophilia have been examined for their ability to use the disaccharide lactose for growth. These organisms lack the usual high levels of $\beta$-galactosidase found in most lactose-positive bacteria, although both strains were found to have high levels of the enzyme lactose dehydrogenase. If this latter enzyme is responsible for all lactose splitting, $P$. maltophilia is unlike other pseudomonads, which have lactose dehydrogenase but which apparently cannot use lactose as a source of carbon and energy for growth.
\end{abstract}

Although Pseudomonas maltophilia has been widely isolated from clinical specimens, water, and raw milk (4), and is probably of widespread occurrence, little is known about either its ecology or its physiology. It does, however, while presenting a remarkably uniform biotype, appear to be nutritionally less versatile than the other aerobic pseudomonads (16). The multitrichous $P$. maltophilia does not accumulate poly$\beta$-hydroxybutyrate as a cellular reserve material and it cannot attack exogenous polymers. $\mathrm{Me}$ thionine is universally required as a growth factor $(5,16)$, and all strains are oxidase negative, hydrolyze gelatin, and are strongly lipolytic. $\mathrm{Ni}$ trate cannot be used as a principal nitrogen source, and organic compounds are only utilized to a limited extent as compared to the other aerobic pseudomonads. Notable, however, is its ability to use the disaccharides lactose, maltose, and cellobiose. Cell growth with lactose as substrate is slow and low cell yields are obtained (perhaps because galactose [one of the possible end products after the breakdown of lactose ] is not attacked [16]). A full description of the species is given by Stanier et al. (16): the type strain is $P$. maltophilia 67 (ATCC 13637, originally \#810-2 of Hugh).

Previously, the growth of an organism with lactose as the sole carbon source was considered to indicate the presence of $\beta$-galactosidase ( $\mathrm{EC}$ 3.2.1.23 $\beta$-D-galactoside galactohydrolase) (8). However, the breakdown of lactose to more utilizable intermediates can be mediated by enzymes other than $\beta$-galactohydrolase.

Recent work has established the presence of an enzyme, $\beta$-D-phosphogalactoside galactohydrolase, in some microbes which hydrolyzes lactose-phosphate after phosphorylation by a phosphoenolpyruvate (PEP) transferase type

${ }^{2}$ Present address: Canada Center for Inland Waters, P.O. Box 5050, Burlington, Ontario, Canada. of system $(6-9,11,14,15)$. Other enzymes found in pseudomonads (such as $P$. graveolans) catalyze the formation of lactobionic acid via lactobionic $\delta$-lactone after direct oxidation of lactose by two enzymes, lactose dehydrogenase and lactobionic $\delta$-lactone lactonase $(1,12,13)$. No carbon atoms in the resulting compound, lactobionic acid, are used for cell synthesis. However, in Streptococcus lactis UN, an organism which has the same enzymes (17), lactobionic acid is further hydrolyzed to galactose and gluconate.

The present study was initiated in an attempt to determine the reasons why the routine 0 -nitrophenyl- $\beta$-D-galactopyranoside (ONPG) disk test (Difco) carried out on both $P$. maltophilia strains showed the presence of small amounts of $\beta$-galactosidase in $P$. maltophilia strain 67 (a strain barely able to use lactose in a minimal medium assimilation test), while $P$. maltophilia strain 68 showed only trace activity in the (ONPG) disk test but used lactose (but not galactose) in minimal medium. The utilization of lactose by $P$. maltophilia is slower than that seen in other aerobically grown microbes which use lactose as a sole source of carbon and energy, and it was interesting to examine whether lactose metabolism was unique enough to be used in the characterization or identification of this pseudomonad.

\section{MATERIALS AND METHODS}

Cultures. $P$. maltophilia strains 67 and 68 were obtained from R. Y. Stanier and were subcultured monthly on plate count agar slants at $30 \mathrm{C}$. Escherichia coli ATCC 25922 was taken as a positive control for $\beta$-galactosidase from the stock culture collection, Dairy and Food Science Department, University of Saskatchewan.

Cells for Warburg studies or for enzyme extract preparation were grown in the basal medium de- 
scribed by Stanier et al. (16) at $30 \mathrm{C}$ after addition of the appropriate carbon source(s).

Biochemical studies. The tests and media employed included the following: pigmentation (Trypticase soy agar with $1 \%$ L-tyrosine, reference 3 ); aesculin hydrolysis (Trypticase soy agar with $0.1 \%$ aesculin and $0.05 \%$ ferric citrate); gelatin hydrolysis (nutrient agar plus $0.4 \%$ gelatin plates later flooded with $15 \%$ $\mathrm{HgCl}_{2}$ in dilute $\mathrm{HCl}$ ); lysine carboxylase (10); $\beta$-galactosidase qualitative test (ONPG differentiation discs [Difco]); oxidase test (cytochrome oxidase test papers [Pathotec, Warner Chilcott Laboratories]). The basal medium for carbon assimilation studies contained, per $1,000 \mathrm{ml}$ of water: methionine (when needed), 10 $\mathrm{mg} ;\left(\mathrm{NH}_{4}\right)_{2} \mathrm{SO}_{4}, 2.0 \mathrm{~g} ; \mathrm{NaH}_{2} \mathrm{PO}_{4} \cdot \mathrm{H}_{2} \mathrm{O}, 0.5 \mathrm{~g}$; $\mathrm{K}_{2} \mathrm{HPO}_{4}, 0.5 \mathrm{mg} ; \mathrm{MgSO}_{4} \cdot 7 \mathrm{H}_{2} \mathrm{O}, 0.2 \mathrm{~g} ; \mathrm{CaCl}_{2} \cdot 2 \mathrm{H}_{2} \mathrm{O}$, $0.1 \mathrm{~g}$. The respective carbon sources were added to the basal medium to give a final concentration of $0.03 \mathrm{M}$. The medium was at $\mathrm{pH} 6.5$. Heat labile substrates were sterilized by membrane filtration (Millipore Corp.). All cultures were incubated for 4 to 7 days at $30 \mathrm{C}$ prior to testing.

Preparation of cell-free extracts. Cells were washed twice and resuspended in $0.05 \mathrm{M} \mathrm{pH} 7.0$ phosphate buffer at 4,000 to $5,000 \mathrm{Klett}$ units $/ \mathrm{ml}(40 \times$ growth concentration, about $17 \mathrm{mg}$ [dry weight] per $\mathrm{ml})$. Deoxyribonuclease $(1,200 \mathrm{U} / \mathrm{mg}$, Worthington Biochemical Corp., Freehold, N. J.) was added at 100 $\mu \mathrm{g} / \mathrm{ml}$ to eliminate viscosity. Extracts were prepared from logarithmically growing cells using a French pressure cell at 18,000 to $20,000 \mathrm{lb} / \mathrm{in}^{2}$ and then centrifuged in the cold at $25,000 \times g$ for $15 \mathrm{~min}$. Toluene-treated cells were made as described by Premi et al. (14).

Enzyme assays: $\beta$-galactosidase. To a tube containing $3.0 \mathrm{ml}$ of sodium phosphate buffer ( $\mathrm{pH} 7.25$ ) equilibrated at $30 \mathrm{C}$ was added $1.0 \mathrm{ml}$ of $0.01 \mathrm{M}$ $\beta$-o-nitrophenylgalactoside and $1.0 \mathrm{ml}$ of suitably diluted enzyme. After incubation at $30 \mathrm{C}$ for the designated time intervals, samples of $0.5 \mathrm{ml}$ were removed and added to Spectronic 20 tubes containing $8.5 \mathrm{ml}$ of water and $1.0 \mathrm{ml}$ of $1.0 \mathrm{M}$ sodium carbonate. The optical density (OD) was read at $420 \mathrm{~nm}$, and values were compared to a standard curve to $o$-nitrophenol.

Enzyme assays: lactose dehydrogenase. The lactose dehydrogenase assay was conducted using a modified Vakil and Shahani method (17). Cuvettes contained $100 \mu \mathrm{mol}$ of sodium phosphate buffer $(\mathrm{pH}$ 6.5), $0: 1 \mu \mathrm{mol}$ of dichlorophenolindophenol dissolved in tris(hydroxymethyl)aminomethane (Tris) buffer ( $\mathrm{pH} \mathrm{8.0)}$ (total of $0.5 \mu \mathrm{mol}$ of Tris buffer in cuvette), enzyme, $10 \mu \mathrm{mol}$ of lactose, and water to a total volume of $3 \mathrm{ml}$. All assays were performed at $22 \mathrm{C}$ on a Gilford 2400 automatic recording spectrophotometer at $590 \mathrm{~nm}$ using the $0.1 \mathrm{OD}$ expanded scale.

Enzyme assays: $\beta$-D-phosphogalactoside galactohydrolase. A sample of cell-free extract or toluenetreated cells was incubated for appropriate time intervals with $10 \mu \mathrm{mol}$ of $o$-nitrophenylgalactoside6-phosphate (Sigma Chemical Co., St. Louis, Mo.) made in $0.05 \mathrm{M}$ sodium phosphate buffer ( $\mathrm{pH} 7$ ) (100 $\mu \mathrm{mol}$ of buffer in assay). The reaction was stopped with $1,250 \mu \mathrm{mol}$ of sodium carbonate. Readings were made at $420 \mathrm{~nm}$.

Warburg respirometer experiments. Warburg respirometer analysis of the ability of $P$. maltophilia to oxidize succinate, glucose, galactose, and lactose were carried out using a Precision Scientific standard Warburg respirometer. Logarithmically growing cells in $10 \mathrm{mM}$ lactose, methionine $(11 \mu \mathrm{g} / \mathrm{ml})$ (minimal medium [16]) were harvested, washed twice, and resuspended to 2,000 Klett units/ml (approximately 7 $\mathrm{mg}$ [dry weight $/ \mathrm{ml}$ ). Warburg cups contained 100 $\mu \mathrm{mol}$ of $\mathrm{pH} 6.8$ sodium phosphate buffer, cells, and 5 $\mu \mathrm{mol}(2.5 \mu \mathrm{mol}$ for lactose) of the appropriate substrate. Cells were examined after 18 and $85 \mathrm{~h}$ of growth.

\section{RESULTS AND DISCUSSION}

The identity of $P$. maltophilia strains 67 and 68 obtained from R. Y. Stanier and subcultured in our lab was verified prior to initiating these experiments. The biochemical tests considered important (16) were carried out and the results are outlined in Tables 1 and 2. Both organisms were easily confirmed as $P$. maltophilia. However, although $P$. maltophilia 67 (the type species) showed the usual $(2,6)$ methionine

TABle 1. Identification tests for Pseudomonas maltophilia

\begin{tabular}{l|l|l}
\hline \multicolumn{1}{c|}{ Test } & Strain 67 & \multicolumn{1}{c}{ Strain 68} \\
\hline Pigment production & + (slow) & + \\
Aesculin hydrolysis & + & + \\
Gelatin hydrolysis & + & + \\
Casein hydrolysis & + & + \\
Lysine decarboxylase & + (slow) & + (slow) \\
ONPG disk: & & \\
$\quad$ (i) whole cells & + (slow) & \pm (very slow) \\
$\quad$ (ii) toluene extracts & - & - \\
Cytochrome oxidase & - & - \\
\hline
\end{tabular}

TABLE 2. Assimilation tests for Pseudomonas maltophilia

\begin{tabular}{l|c|c|c|c}
\hline \multirow{2}{*}{\multicolumn{1}{c|}{ Substrate }} & \multicolumn{2}{c|}{ Strain 67 } & \multicolumn{2}{c}{ Strain 68 } \\
\cline { 2 - 5 } & $\begin{array}{c}\text { No } \\
\text { meth- } \\
\text { ionine }\end{array}$ & $\begin{array}{c}\text { Meth- } \\
\text { ionine }\end{array}$ & $\begin{array}{c}\text { No } \\
\text { meth- } \\
\text { ionine }\end{array}$ & $\begin{array}{c}\text { Meth- } \\
\text { ionine }\end{array}$ \\
\hline Succinate & - & + & + & + \\
Acetate & - & + & + & + \\
Glycerol & - & - & - & - \\
Galactose & - & + & - & - \\
Glucose & - & + & - & \pm \\
Lactose & - & + & - & + \\
Maltose & - & + & - & + \\
Cellibiose & - & + & - & + \\
Gluconate & - & - & - & - \\
Lactobionate & - & - & - & - \\
\hline
\end{tabular}


requirement, strain 68 showed no such requirement if succinate or acetate was used as a carbon source. Care should therefore be taken in concluding that no strain can grow in standard synthetic medium furnished with $\mathrm{NH}_{4}^{+}$as nitrogen source and any readily utilizable carbon and energy source (16).

To establish conclusively that lactose is utilized by both organisms, growth studies were carried out using Pseudomonas basal medium (16), supplemented with $0.1 \%$ nutrient broth and $100 \mu \mathrm{g}$ of methionine per $\mathrm{ml}$, with and without $10 \mathrm{mM}$ lactose. To determine whether growth is promoted by the addition of lactose, values obtained in flasks without lactose were subtracted from the corresponding flasks with lactose. This corrects for growth occurring from substrates in the nutrient broth. The nutrient broth addition allows such growth curves to be completed in reasonable time intervals and gives results more consistent than those obtained in lactose-methionine basal medium alone, although the results are similar. The twoto threefold increase in cell yield over nutrient broth values shown in curves in Fig. 1 demonstrates that increased cell yields are in fact achieved at the expense of lactose additions to the medium and that some energy and carbon must be derived from lactose. This is contrary to the results described with other pseudomonads (8).

P. maltophilia cell-free extracts were also examined for $\beta$-galactosidase activity. ONPG disks (Difco) had indicated extremely low levels of $\beta$-galactosidase, especially with strain 68 . The results of the enzyme assay using either $\beta$-o-nitrophenylgalactoside (spectrophotometric assay) or lactose (glucostat assay) as substrates were both negative after assay incubation times of 15 to $30 \mathrm{~min}$ as normally used with $E$. coli. However, when the hydrolysis of ONPG was examined in tubes incubated up to $7 \mathrm{~h}$, distinct activity was recorded. A long-term assay was therefore conducted to obtain enzyme rates (Table 3). Strain 68 appeared to have considerably more enzyme than did strain 67 . However, both these enzyme levels were considered to be very low in comparison to $E$. coli, an organism which grows extremely quickly at the expense of lactose even in minimal media.

Failure of the extracts to hydrolyze ONPR at significant rates may have been an indication that $\beta$-galactosidase was not the enzyme responsible for lactose hydrolysis but that another system, such as the PEP phosphotransferase reaction $(6,11)$, was operating. The presence of the enzymes $\beta$-o-phosphogalactosidegalactohy- drolase and lactose dehydrogenase $(8,12,13)$ was therefore investigated. The results are shown in Table 4. It can be seen that lactose dehydrogenase is present in reasonable amounts in extracts of both $P$. maltophilia strains. The enzyme appears to be similar to that found by Nishizuka and Hayaishi $(12,13)$ in that it is constitutive and also acts on aldoses other than lactose. Preliminary results, however, would indicate that it is a soluble enzyme in $P$.

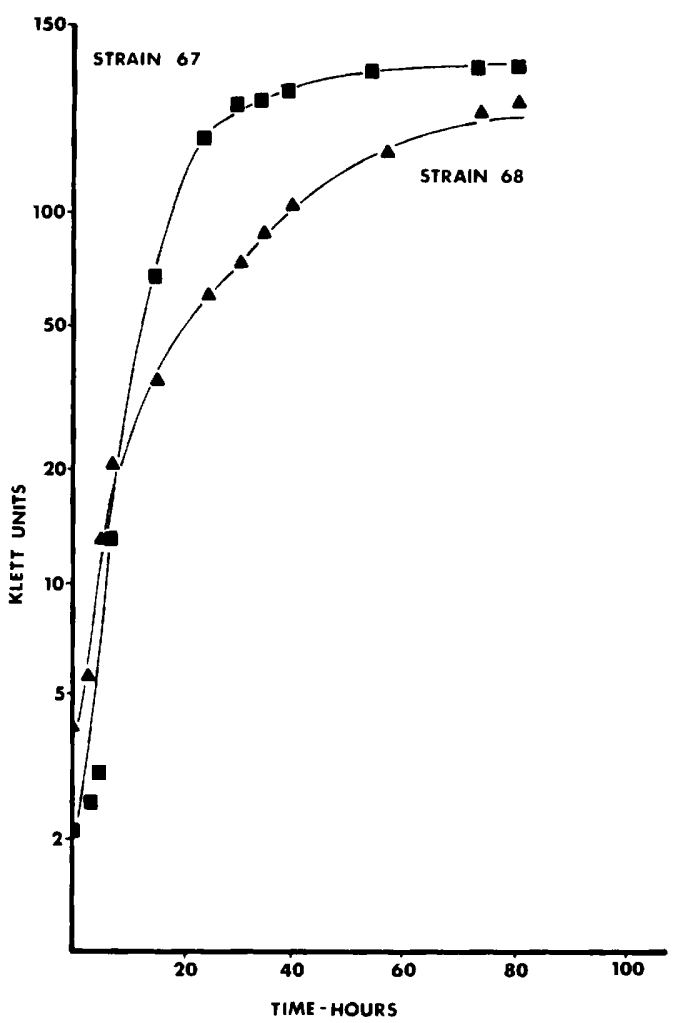

Fig. 1. Growth occurring in supplemented minimal medium due to the substrate lactose. Growth resulting from utilizable substrates in nutrient broth has been subtracted (a maximum of 100 Klett units, approximately $350 \mu \mathrm{g}$ [dry weight $] / \mathrm{ml}$, was observed in the first $16 \mathrm{~h}$ in flasks where P. maltophilia 67 or 68 was grown on nutrient broth alone).

Table 3. $\beta$-galactosidase levels in Pseudomonas maltophilia

\begin{tabular}{l|c}
\hline \multicolumn{1}{c|}{ Organism } & \multicolumn{1}{c}{$\begin{array}{c}\text { Enzyme activity } \\
(\mu \mathrm{mol} \text { of ONP } \\
\text { min/mg protein })\end{array}$} \\
\hline E. coli ATCC 25922 & $4.98 \times 10^{-1}$ \\
P. maltophilia 67 & $9.8 \times 10^{-5}$ \\
P. maltophilia 68 & $2.5 \times 10^{-3}$ \\
\hline
\end{tabular}

${ }^{a}$ o-Nitrophenol. 
TABLE 4. Lactose dehydrogenase and $\beta$-o-phosphogalactosidehydrolase levels in P. maltophilia

\begin{tabular}{l|c|c|c}
\hline \multirow{2}{*}{ Organism } & $\begin{array}{c}\text { Lactose dehydrogenase } \\
(\mu \text { mol of DCPIP reduced } \\
\text { min/mg protein })\end{array}$ & Cell-free extracts & Toluene extracts \\
\cline { 3 - 4 } & 0 & ND $^{a}$ & ND \\
E. coli ATCC 25922 & $1.9 \times 10^{-2}$ & 0 & 0 \\
P. maltophilia 67 & $1.71 \times 10^{-1}$ & 0 & 0 \\
P. maltophilia 68 &
\end{tabular}

${ }^{a} \mathrm{ND}$, not done.

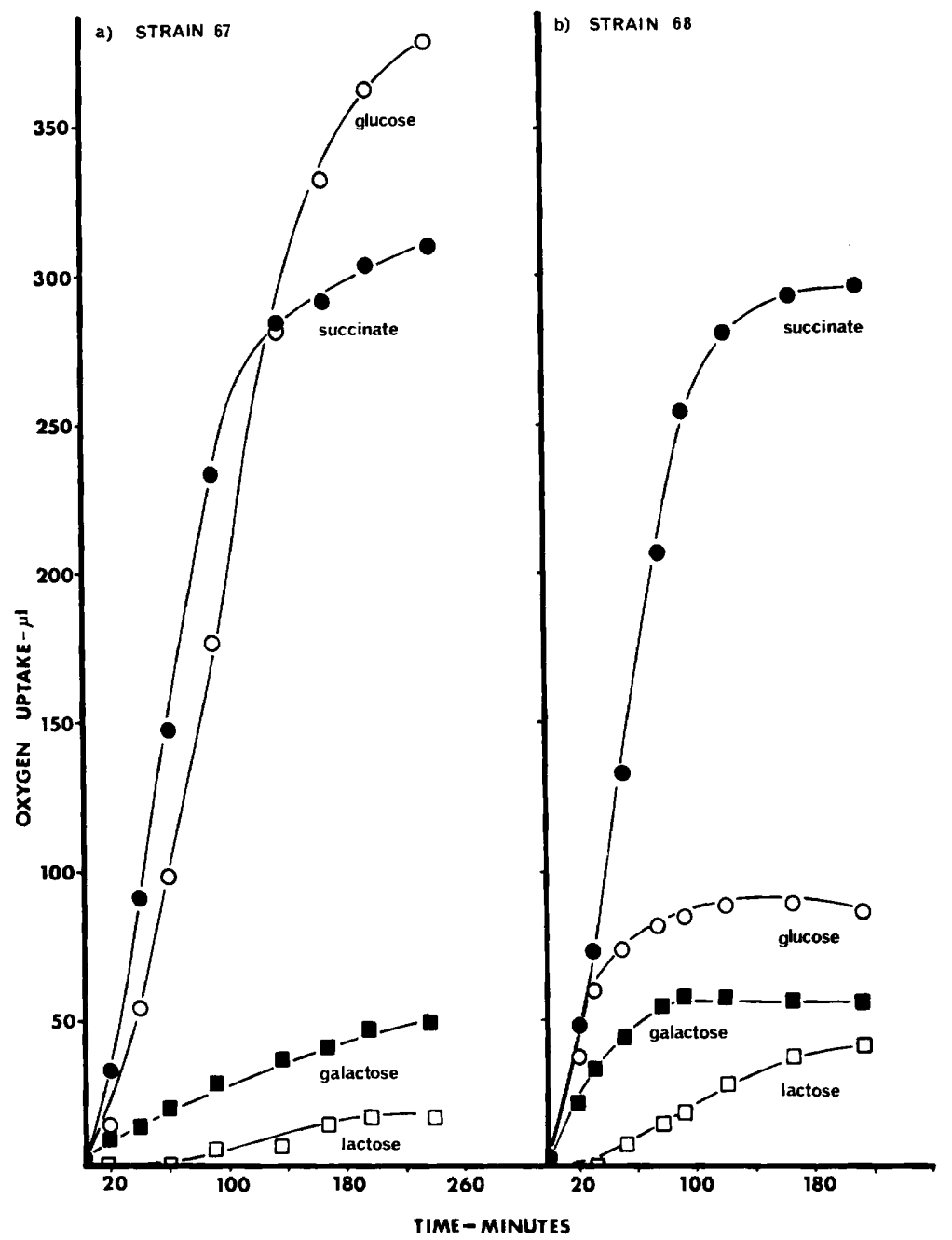

Fig. 2. Oxygen uptake from various substrates by $P$. maltophilia 67 and 68 as measured by the Warburg respirometer.

maltophilia. No attempts, however, have been made to purify the enzyme or remove all membranous material from the crude extracts as the solubilities of the other enzymes in the system are not known. Lactose dehydrogenase may account for utilization of lactose by these organisms, although the end products of lactobionic acid splitting, if this step takes place in $P$. maltophilia, would be gluconate and galactose. From growth studies using exogenous substrates we have been unable to show significant utilization of either of these compounds by strain 68 , although strain 67 will use galactose. Moreover, in Warburg experiments (Fig. 2a and b) with 
whole cells, the rates and extents of utilization of lactose and galactose are considerably poorer than that of glucose, and under the experimental conditions gluconate is not attacked regardless of whether early logarithmic- or stationary-phase cells are used.

It has been suggested by a number of authors (see reference 8 ) that mutant cells which lose the ability to ferment a number of different carbohydrates through a single gene effect may be general pleotropic mutants for carbohydrate transport because of a restricted or lost component of the PEP-phosphotransferase system. We have been unable to demonstrate any activity of what would be the key enzyme (14) of the PEP lactose phosphotransferase system, $\beta$-Dphosphogalactoside galactohydrolase (hydrolyzes lactose phosphate, the phosphorylation of which is mediated by PEP, to liberate glucose and galactose-6-phosphate). This enzyme usually hydrolyzes ONPG-6-P in cell-free extracts and toluene-treated cells but will not hydrolyze ONPG under similar conditions $(7,14)$. We were unable to demonstrate the enzyme in extracts or toluene preparations of whole $P$. maltophilia 67 or 68 cells. Although this organism does not seem to have the PEP phosphotransferase system functioning to transport carbohydrate into the cell from the surrounding medium, it would seem that a generalized transport problem does exist in $P$. maltophilia for hexoses and disaccharides, as shown by growth and respirometer studies. It may be possible that low levels of lactose permease result in slow entry of lactose into the cell. Nevertheless, it would appear that lactose, once inside the cell, is readily attacked by lactose dehydrogenase. The fate of the resulting lactobionic acid and gluconate in strains 67 and 68 and galactose in strain 68 have not conclusively been determined. Other than fermentation patterns (16), carbohydrate metabolism and transport have not yet been investigated to our knowledge in this organism.

No easily conducted enzyme assay or test suitable for identification or characterization which is unique for $P$. maltophilia can be proposed for these results, although the profile of lactose metabolism appears to be different from other pseudomonads (1) and gram-negative, lactose-positive rods.

\section{ACKNOWLEDGMENTS}

This investigation was supported in part by funds provided by the Dairy and Food Science Department, University of Saskatchewan, and by National Research Council of
Canada Grant A6478. The technical assistance of G. Butany and A. Joorisity was much appreciated.

\section{REPRINT REQUESTS}

Address reprint requests to: Dr. W. M. Ingledew, Department of Dairy and Food Science, University of Saskatchewan, Saskatoon, Saskatchewan, S7N 0W0, Canada.

\section{LITERATURE CITED}

1. Bently, R., and L. Slechta. 1960. Oxidation of mono- and disaccharides to aldonic acids by Pseudomonas species. J. Bacteriol. 79:346-355.

2. Citti, J. E., W. E. Sandine, and P. R. Elliker. 1965 $\beta$-galactosidase of Streptococcus lactis. J. Bacteriol. 89:937-942.

3. Gilardi, G. L. 1971. Characterization of nonfermentative nonfastidious Gram negative bacteria encountered in medical bacteriology. J. Appl. Bacteriol. 34:623-644.

4. Hugh, R., and E. Ryschenkow. 1961. Pseudomonas maltophilia, an Alcaligenes-like species. J. Gen. Microbiol. 26:123-132.

5. Iizuka, H., and K. Komagata. 1964. Microbiological studies on petroleum and natural gas. I. Determination of hydrocarbon-utilizing bacteria. J. Gen. Appl. Microbiol, 10:207-221.

6. Kennedy, E. P., and G. A. Scarborough. 1967. Mechanism of hydrolysis of 0 -nitrophenyl- $\beta$-galactoside in Staphylococcus aureus and its significance for theories of sugar transport. Proc. Nat. Acad. Sci. U.S.A. 58:225 228.

7. McKay, L. L., A. Miller III, W. E. Sandine, and P. R Elliker. 1970. Mechanisms of lactose utilization by lactic acid streptococci: enzymatic and genetic analyses. J. Bacteriol. 102:804-809.

8. McKay, L. L., W. E. Sandine, and P. R. Elliker. 1971. Lactose utilization by lactic acid bacteria: a review. Dairy Sci. Abstr. 33:493-499.

9. McKay, L. L., L. A. Walter, W. E. Sandine, and P. R Elliker. 1969. Involvement of phosphoenolpyruvate in lactose utilization by group $\mathrm{N}$ streptococci. J. Bacteriol. 99:603-610.

10. Møller, V. 1955. Simplified tests for some amino acid decarboxylases and for the arginine dihydrolase system. Acta Pathol. Microbiol. Scand. 36:158-172.

11. Molskness, T. A., D. R. Lee, W. E. Sandine, and P. R. Elliker. 1973. $\beta$-D-phosphogalactoside galactohydrolase of lactic streptococci. Appl. Microbiol. 25:373-380.

12. Nishizuka, Y., and O. Hayaishi. 1962. Enzymic formation of lactobionic acid from lactose. J. Biol. Chem. 237:2721-2728.

13. Nishizuka, Y., S. Kuno, and O. Hayaishi. 1960. Lactose dehydrogenase, a new flavoprotein. J. Biol. Chem. 235:PC 13-14.

14. Premi, L., W. E. Sandine, and P. R. Elliker. 1972. Lactose-hydrolyzing enzymes of Lactobacillus species. Appl. Microbiol. 24:51-57.

15. Simoni, R. D., T. Nakazawa, J. B. Hays, and S. Roseman. 1973. Sugar transport. IV. Isolation and characterization of the lactose phosphotransferase system in Staphylococcus aureus. J. Biol. Chem. 248:932-940.

16. Stanier, R. Y., N. J. Palleroni, and M. Doudoroff. 1966. The aerobic pseudomonads: a taxonomic study. J. Gen. Microbiol. 43:159-271.

17. Vakil, J. R., and K. M. Shahani. 1968. Carbohydrate metabolism of lactic acid cultures. II. Different path. ways of lactose metabolism of Streptococcus lactis and their sensitivity to antibiotics. J. Dairy Sci. 52:162-168. 